\title{
Effect of Various Organic Manures and Bio-fertilizers on Growth and Yield of Chilli (Capsicum annum L.) under Temperate Conditions of Kashmir
}

\author{
Afiya Khurshid*, Faheema Mushtaq, Sumati Narayan, Shahnaz Mufti, Rehana Rasool, \\ Iqtab Mushtaq Wani, Sameena Maqbool, Mir Tabasum Ashraf, Usma Jan, \\ Humaira Nazir and Nawaz Ahmed
}

\author{
Division of Vegetable Science, Sher-e-Kashmir University of Agricultural Sciences and \\ Technology of Kashmir, Shalimar, J\&K, India \\ *Corresponding author
}

\section{A B S T R A C T}

\section{Keywords}

\section{Chilli, Organic} manures (FYM, poultry manure, Vermicompost, Mustard cake, Biofertilizers, Growth, Yield

Article Info

Accepted:

25 December 2020

Available Online:

10 January 2021
The experiment was carried out at Vegetable Experimental Farm, SKUAST-K Shalimar Campus to find out the effect of different organic manures and bio-fertilizers on growth and yield of chilli var. Kashmir Long-1. The experiment was laid out in RCBD design with ten treatments viz. $100 \%$ FYM, $100 \%$ poultry manure, $100 \%$ vermicompost, $100 \%$ mustard cake, $75 \%$ FYM + biofertilizers, $75 \%$ poultry manure + biofertilizers, $75 \%$ vermicompost + biofertlizers, $75 \%$ mustard cake + biofertilizers, $100 \%$ biofertilizers and absolute control which were replicated three times. The investigation revealed that the treatment $\mathrm{T}_{7}(75 \%$ vermicompost + biofertilizer) recorded minimum number of days to first flowering (30.15), days to first fruit set (37.90), days to 50\% colour development (89.07) and days to first fruit maturity (96.38) whereas, treatment. Moreover, treatment $\mathrm{T}_{7}$ (75\% vermicompost + biofertilizer) recorded higher values for plant height $(52.55 \mathrm{~cm})$, plant spread $(47.76 \mathrm{~cm})$ and number of branches plant ${ }^{-1}(8.43)$ whereas minimum values for plant height $(30.24 \mathrm{~cm})$, plant spread $(3.18 \mathrm{~cm})$ and number of branches plant $^{-1}(3.47)$ were recorded by treatment $\mathrm{T}_{10}$ (absolute control). The yield parameters like the number of fruits plant ${ }^{-1}(54.39)$, fruit length $(10.30 \mathrm{~cm})$, fruit girth $(1.76 \mathrm{~cm})$, average fruit weight $(7.43 \mathrm{~g})$, fruit yield plant $^{-1}(404.47 \mathrm{~g})$, fruit yield hectare $^{-1}(149.68 \mathrm{q})$ were recorded maximum in treatment $\mathrm{T}_{7}\left(75 \%\right.$ vermicompost + biofertilizer). Treatment $\mathrm{T}_{10}$ (absolute control) recorded minimum values for various yield parameters.

\section{Introduction}

Chilli also known as hot pepper (Capsicum annum var. annum L.), is an inevitable condiment and vegetable grown extensively throughout the world. It is a member of the nightshade family, Solanaceae. Chilli plays a major role in the Indian diet and is used as a condiment in various food stuffs like curries, sauces, soups and chutney to add flavour and pungency and also widely used in the preparation of curry powder. Green chilli fruits are eaten raw as salad and powder of dry chillies is an indispensable spice of every kitchen throughout India. Dried chilli fruits constitute a significant share of the spices 
consumed per head (Koshale et al., 2018). In Indian subcontinent, chilli is cultivated over an area of 844 thousand ha with an annual production of 2106 thousand metric tons (Anonymous, 2018). While as in Jammu and Kashmir it occupies an area of 0.60 thousand hectares with an annual production of 0.40 thousand metric tonnes (Anonymous, 2017). Chillies are grown in almost all the states throughout the year.

The intension of increased yield and profit has led to widespread use of high doses of concentrated chemical fertilizer and simultaneous inadequate use of organic products, which has led to a decline in soil fertility and soil structure. Also excessive use of mineral fertilizers has aroused environmental concern. Therefore to maintain a healthy ecosystem, an alternative farming system which is sustainable and self-sufficient such as organic farming needs to be adopted (Behera et al., 2012).

Organic manures not only provide macro, micro and secondary nutrients but also enhance the soil's physical, chemical and biological properties. Organic manures are slow to release, so they are less vulnerable to failure than inorganic fertilizers, which in turn minimize soil, water and air pollution (Bade et al., 2017). In recent years biofertilizers viz Azospirillium, Phosphate Solubilizing Bacteria and Potassium Solubilizing Bacteria that are eco-friendly and low cost inputs have also emerged as an important and integral component of integrated plant nutrient supply system for vegetable production.

Considering the above cited points and keeping in view the importance of organic nutrients, the present study was undertaken with the objective to find out the response of chilli to organic cultivation in terms of growth and yield.

\section{Materials and Methods}

The study to evaluate the response of organic manure in case of Chilli plantation var. Kashmir Long-1was conducted at Vegetable Experimental Farm, SKUAST-Kashmir during Kharif 2019. The experiment was laid out in Randomized Complete Block Design and consisted of ten treatments and three replications. The field was divided into 30 plots of $3.5 \times 2.5 \mathrm{~m}^{2}$ plot size to accommodate 30 plants at a spacing of $60 \times 45 \mathrm{~cm}$ per plot. $30 \mathrm{~cm}$ wide bunds were made between the replications. The soil of the experimental field was clayey loam with a $\mathrm{pH}$ of 7.11 . The treatment details are presented in table 1 .

\section{Results and Discussion}

\section{Observations on growth parameters}

The results presented in table 2 revealed significant effects of different treatments on various growth parameters. Minimum number of days to first flowering (30.15), first fruit set (37.90), 50\% colour development (89.07) and first fruit maturity (96.38) were recorded with treatment $\mathrm{T}_{7} \quad(75 \%$ vermicompost + biofertilizer) whereas the maximum values i.e., 40.31, 50.32, 97.34, 106.73 of the said parameters respectively were registered with treatment $\mathrm{T}_{10}$ (absolute control). However, for days to first fruit set treatment $\mathrm{T}_{7}(75 \%$ vermicompost + biofertilizer) was statistically at par with treatment $\mathrm{T}_{6}(75 \%$ poultry manure + biofertilizer). Earliness is a trait that is governed by nutrition availability as the nutrients play a pivotal role in the synthesis of plant hormones like auxins, gibberlins and cytokinins which in turn cause early initiation of flowers. Vermicompost being rich in all important plant nutrients has an excellent impact on the overall growth and production of plants, and biofertilizers improve the supply and availability of nutrients to plants. Besides, various plant hormones are released 
due to metabolisms in microbes present in vermicompost thereby increasing their concentration. Moreover, swift vegetative growth might have resulted in accumulation of ample food materials for transformation of buds into floral buds resulting in early flowering and ensuing first fruit harvest. Same results were reported by Pariari and Khan (2013) in chilli and Jamir et al., (2017) in sweet pepper.

Table. 1 Treatment details

\begin{tabular}{|c|c|c|}
\hline Treatments & \multicolumn{1}{|l|}{ Details } & Structure \\
\hline $\mathbf{T}_{\mathbf{1}}$ & 100\% FYM & $24 \mathrm{t} / \mathrm{ha}$ \\
\hline $\mathbf{T}_{\mathbf{2}}$ & 100\% Poultry Manure & $8 \mathrm{t} / \mathrm{ha}$ \\
\hline $\mathbf{T}_{\mathbf{3}}$ & 100\% Vermicompost & $4 \mathrm{t} / \mathrm{ha}$ \\
\hline $\mathbf{T}_{\mathbf{4}}$ & 100\% Mustard Cake & $2.5 \mathrm{t} / \mathrm{ha}$ \\
\hline $\mathbf{T}_{\mathbf{5}}$ & 75\% FYM + Biofertilizers & $18 \mathrm{t} / \mathrm{ha}+$ Biofertilizer $^{* *}$ \\
\hline $\mathbf{T}_{\mathbf{6}}$ & 75\% Poultry Manure + Biofertilizer & $6 \mathrm{t} / \mathrm{ha}+$ Biofertilizer $^{* *}$ \\
\hline $\mathbf{T}_{\mathbf{7}}$ & $75 \%$ Vermicompost + Biofertilizer & $3 \mathrm{t} / \mathrm{ha}+$ Biofertilizer $^{* *}$ \\
\hline $\mathbf{T}_{\mathbf{8}}$ & $75 \%$ Mustard Cake + Biofertilizer & $1.8 \mathrm{t} / \mathrm{ha}+$ Biofertilizer $^{* *}$ \\
\hline $\mathbf{T}_{\mathbf{9}}$ & 100\% Biofertilizer & $5 \mathrm{t} / \mathrm{ha}$ \\
\hline $\mathbf{T}_{\mathbf{1 0}}$ & Absolute Control & - \\
\hline
\end{tabular}

*FYM- Farm yard manure

*** Soil application of biofertilizers viz. Azotobacter, PSB and KSB were given @ 5 L/ha

Table2 Effect of organic manures on days to first flowering, first fruit set, 50\% colour development and first fruit maturity

\begin{tabular}{|c|c|c|c|c|}
\hline Treatment & $\begin{array}{l}\text { Days to first } \\
\text { flowering }\end{array}$ & $\begin{array}{l}\text { Days to first } \\
\text { fruit set }\end{array}$ & $\begin{array}{l}\text { Days to } 50 \% \\
\text { colour } \\
\text { development }\end{array}$ & $\begin{array}{l}\text { Days to first } \\
\text { fruit maturity }\end{array}$ \\
\hline $\mathbf{T}_{1}$ & $33.68^{c}$ & $42.59^{\mathrm{cd}}$ & $91.15^{\mathrm{c}}$ & $99.45^{\mathrm{d}}$ \\
\hline $\mathbf{T}_{2}$ & $33.18^{d}$ & $41.88^{\mathrm{d}}$ & $90.56^{d}$ & $98.65^{\mathrm{e}}$ \\
\hline $\mathbf{T}_{3}$ & $32.37^{\mathrm{e}}$ & $40.27^{\mathrm{e}}$ & $90.24^{\mathrm{e}}$ & $98.16^{\mathrm{f}}$ \\
\hline $\mathbf{T}_{4}$ & $34.02^{c}$ & $43.05^{c}$ & $91.25^{\mathrm{c}}$ & $99.97^{\mathrm{c}}$ \\
\hline$T_{5}$ & $31.21^{\mathrm{g}}$ & $39.10^{\mathrm{fg}}$ & $89.72^{\mathrm{f}}$ & $97.44^{\mathrm{g}}$ \\
\hline$T_{6}$ & $30.89^{\mathrm{g}}$ & $38.52^{\mathrm{gh}}$ & $89.34^{\mathrm{g}}$ & $96.86^{\mathrm{h}}$ \\
\hline $\mathbf{T}_{7}$ & $30.15^{\mathrm{h}}$ & $37.90^{\mathrm{h}}$ & $89.07^{\mathrm{h}}$ & $96.38^{1}$ \\
\hline $\mathbf{T}_{8}$ & $31.92^{\mathrm{f}}$ & $39.97^{\text {ef }}$ & $90.06^{e}$ & $97.84^{\mathrm{fg}}$ \\
\hline $\mathbf{T}_{9}$ & $37.44^{\mathrm{b}}$ & $48.92^{b}$ & $94.83^{b}$ & $103.65^{\mathrm{b}}$ \\
\hline $\mathbf{T}_{10}$ & $40.31^{\mathrm{a}}$ & $50.32^{\mathrm{a}}$ & $97.34^{\mathrm{a}}$ & $106.73^{\mathrm{a}}$ \\
\hline SE(m) & 0.147 & 0.342 & 0.089 & 0.138 \\
\hline $\mathrm{CD}(\mathrm{p} \leq 0.05)$ & 0.442 & 1.028 & 0.267 & 0.415 \\
\hline
\end{tabular}

Values with different superscripts differ significantly 
Table.3 Effect of organic manures on plant height $(\mathrm{cm})$, plant spread $(\mathrm{cm})$ and number of branches plant ${ }^{-1}$

\begin{tabular}{|c|c|c|c|}
\hline Treatment & Plant height & Plant spread & Number of branches plant ${ }^{-1}$ \\
\hline $\mathbf{T}_{1}$ & $51.05^{\mathrm{g}}$ & $46.05^{\mathrm{e}}$ & $5.76^{\mathrm{f}}$ \\
\hline $\mathbf{T}_{2}$ & $51.21^{\mathrm{f}}$ & $46.31^{\mathrm{e}}$ & $6.19^{e}$ \\
\hline $\mathbf{T}_{3}$ & $51.36^{\mathrm{e}}$ & $46.76^{\mathrm{d}}$ & $6.84^{d}$ \\
\hline $\mathbf{T}_{4}$ & $50.72^{\mathrm{h}}$ & $45.72^{f}$ & $5.23^{\mathrm{g}}$ \\
\hline $\mathbf{T}_{5}$ & $51.99^{\mathrm{c}}$ & $46.96^{\mathrm{cd}}$ & $7.66^{b}$ \\
\hline $\mathbf{T}_{6}$ & $52.08^{\mathrm{b}}$ & $47.28^{\mathrm{b}}$ & $8.22^{\mathrm{a}}$ \\
\hline $\mathbf{T}_{7}$ & $52.55^{\mathrm{a}}$ & $47.76^{\mathrm{a}}$ & $8.43^{\mathrm{a}}$ \\
\hline $\mathbf{T}_{8}$ & $51.73^{d}$ & $46.91^{\mathrm{cd}}$ & $7.15^{c}$ \\
\hline $\mathbf{T}_{9}$ & $40.35^{\mathrm{i}}$ & $40.65^{\mathrm{g}}$ & $4.74^{h}$ \\
\hline $\mathbf{T}_{10}$ & $30.24^{j}$ & $30.18^{h}$ & $3.47^{\mathrm{i}}$ \\
\hline SE (m) & 0.024 & 0.086 & 0.088 \\
\hline $\mathrm{CD}(\mathrm{p} \leq 0.05)$ & 0.073 & 0.260 & 0.264 \\
\hline
\end{tabular}

Values with different superscripts differ significantly

Table.4 Effect of various organic manures on yield and yield attributing parameters

\begin{tabular}{|c|c|c|c|c|c|c|}
\hline Treatment & $\begin{array}{l}\text { No. of fruits } \\
\text { plant }^{-1}\end{array}$ & $\begin{array}{c}\text { Average } \\
\text { fruit } \\
\text { weight(g) }\end{array}$ & $\begin{array}{l}\text { Fruit } \\
\text { length } \\
(\mathbf{c m})\end{array}$ & $\begin{array}{l}\text { Fruit girth } \\
\text { (cm) }\end{array}$ & $\begin{array}{l}\text { Fruit yield } \\
\text { plant }^{-1}(g)\end{array}$ & $\begin{array}{c}\text { Fruit yield } \\
\text { hectare }^{-1} \\
\text { (q) }\end{array}$ \\
\hline $\mathbf{T}_{1}$ & $52.52^{\mathrm{e}}$ & $6.99^{\mathrm{e}}$ & $9.41^{\mathrm{f}}$ & $1.69^{\mathrm{f}}$ & $367.30^{\mathrm{f}}$ & $135.92^{\mathrm{f}}$ \\
\hline $\mathbf{T}_{2}$ & $53.02^{d}$ & $7.13^{d}$ & $9.63^{\mathrm{e}}$ & $1.70^{\mathrm{e}}$ & $378.66^{\mathrm{e}}$ & $140.18^{\mathrm{e}}$ \\
\hline $\mathbf{T}_{3}$ & $53.11^{d}$ & $7.19^{c}$ & $9.65^{\mathrm{de}}$ & $1.72^{c}$ & $381.35^{\mathrm{e}}$ & $141.10^{\mathrm{e}}$ \\
\hline $\mathbf{T}_{4}$ & $52.22^{f}$ & $6.94^{\mathrm{e}}$ & $9.21^{\mathrm{g}}$ & $1.66^{\mathrm{g}}$ & $362.38^{\mathrm{g}}$ & $134.10^{\mathrm{g}}$ \\
\hline $\mathbf{T}_{5}$ & $53.57^{\mathrm{c}}$ & $7.32^{b}$ & $9.87^{c}$ & $1.72^{\mathrm{e}}$ & $392.50^{c}$ & $145.24^{c}$ \\
\hline $\mathbf{T}_{6}$ & $54.05^{b}$ & $7.39^{\mathrm{a}}$ & $10.02^{b}$ & $1.73^{b}$ & $399.61^{b}$ & $147.89^{b}$ \\
\hline $\mathbf{T}_{7}$ & $54.39^{\mathrm{a}}$ & $7.43^{\mathrm{a}}$ & $10.30^{\mathrm{a}}$ & $1.76^{\mathrm{a}}$ & $404.47^{\mathrm{a}}$ & $149.68^{\mathrm{a}}$ \\
\hline $\mathbf{T}_{8}$ & $53.41^{\mathrm{c}}$ & $7.27^{b}$ & $9.69^{\mathrm{de}}$ & $1.71^{\mathrm{d}}$ & $388.68^{\mathrm{d}}$ & $143.88^{\mathrm{d}}$ \\
\hline $\mathbf{T}_{9}$ & $26.20^{\mathrm{g}}$ & $4.62^{\mathrm{f}}$ & $8.68^{h}$ & $1.62^{\mathrm{h}}$ & $121.15^{\mathrm{h}}$ & $44.86^{\mathrm{h}}$ \\
\hline $\mathbf{T}_{10}$ & $20.25^{\mathrm{h}}$ & $4.21^{\mathrm{f}}$ & $7.97^{\mathrm{i}}$ & $1.59^{\mathrm{i}}$ & $85.31^{\mathrm{i}}$ & $31.54^{i}$ \\
\hline SE (m) & 0.09 & 0.017 & 0.042 & 0.003 & 1.031 & 0.357 \\
\hline $\begin{array}{c}\mathrm{CD}(\mathrm{p} \leq \\
\mathbf{0 . 0 5})\end{array}$ & 0.270 & 0.053 & 0.126 & 0.009 & 3.092 & 1.072 \\
\hline
\end{tabular}

Values with different superscripts differ significantly 
Furthermore, the results presented in table 3 depicted that all the treatments significantly increased plant height, plant spread and number of branches plant ${ }^{-1}$. Treatment $\mathrm{T}_{7}$ (75\% vermicompost + biofertilizer) registered maximum plant height $(52.55 \mathrm{~cm})$, plant spread $(47.76 \mathrm{~cm})$ and number of branches plant $^{-1}$ (8.43) compared to treatment $\mathrm{T}_{10}$ (absolute control) which recorded minimum plant height $(30.24 \mathrm{~cm})$, plant spread $(30.18$ $\mathrm{cm})$ and number of branches plant $^{-1}(3.47)$. Also treatment $\mathrm{T}_{7}(75 \%$ vermicompost + biofertilizer) was at par with treatment $\mathrm{T}_{6}$ $(75 \%$ poultry manure + biofertilizer $)$ for number of branches plant ${ }^{-1}$. Increment in the values for the said parameters can be attributed to better availability and more uptake of nutrients. Increased availability of nitrogen might have increased amino acid synthesis which function as the substrate for plant hormone synthesis and in turn resulted in more plant growth by inducing cell division, cell elongation and cell enlargement. The results are in agreement with the findings of Patel et al., (2015), Singh et al., (2014) and Kumar et al., (2016).

\section{Observations on yield parameters}

All the treatments significantly increased the yield and yield attributing parameters. Results presented in table 4showed that maximum value for number of fruits plant $^{-1}$ (54.39), average fruit weight $(7.43 \mathrm{~g})$, fruit length $(10.30 \mathrm{~cm})$, fruit girth $(1.76 \mathrm{~cm})$, fruit yield plant $^{-1}(404.47 \mathrm{~g})$ and fruit yield hectare ${ }^{-1}$ (149.68 q)was recorded by treatment $\mathrm{T}_{7}(75 \%$ vermicompost + biofertilizer). Minimum value for number of fruits plant ${ }^{-1}$ (20.25), average fruit weight $(4.21 \mathrm{~g})$, fruit length $(7.97 \mathrm{~cm})$, fruit girth $(1.59 \mathrm{~cm})$, fruit yield plant $^{-1}(85.31 \mathrm{~g})$ and fruit yield hectare ${ }^{-1}$ ( 31.54 q) was registered in treatment $\mathrm{T}_{10}$ (absolute control). Also, in case of average fruit weight treatment $\mathrm{T}_{7}$ (75\% vermicompost + biofertilizer) was at par with treatment $T_{6}$
(75\% poultry manure + biofertilizer). This increment can be attributed to the balanced carbon nitrogen ratio, increased decomposition, more mineralization, increased availability of macro and micro nutrients, increased solubilisation and nutrient availability by the addition of organic manures and enhanced physiological activity which might have resulted in the build-up of sufficient food reserves for the developing sinks and better portioning towards the developing fruits and thus was reflected as increased fruit size and weight of chilli. Also, all these properties might have caused better root proliferation, better transfer of nutrients and an accelerated synthesis of carbohydrates ultimately leading to increased fruit yield. Similar findings were reported by Madhukumar et al., (2018), Reddy et al., (2017) and Pariari and Das (2017).

\section{References}

Anonymous, 2017. Horticultural Statistics at a Glance 2017, Department of Agriculture.

Anonymous, 2018. Chilli Outlook, Agricultural Market Intelligence Centre, PJTSAU.

Bade, K.K., Bhati, V. and Singh, V.B. 2017. Effect of organic manures and biofertilizers on growth, yield and quality of chilli (Capsicum annum) cv. Pusa Jwala. International Journal of Current Microbiology and Applied Sciences, 6(5):2545-2552.

Behera, K.K., Alam, A., Vats, S., Sharma, H.P. and Sharma, V. 2012. Organic Farming

History and Techniques. In: Agroecology and Strategies for Climate Change,

Sustainable Agriculture Reviews, 8:287-328.

Jamir, T., Rajwade, V.B., Prasad, V.M. and Lyngdoh, C. 2017. Effect of organic 
manures and chemical fertilizers on growth and yield of sweet pepper (Capsicum annum L.) hybrid Indam Bharat in shade net condition. International Journal of Current Microbiology and Applied Sciences, 6(8):1010-1019.

Koshale, C., Kurrey, D.K and Banjare, L.D 2018.Effect of organic manure and inorganic fertilizer on growth, yield and physiological parameter of chilli (Capsicum annum L.).International Journal of Chemical Studies, 6(4):118122.

Kumar, V., Shankar, R., Singh, P.K. 2016. Effect of vermicompost, cow dung and different organic manure combination on growth and yield of chilli crop (Capsicum annum L) in India. International Journal of Advances in Agricultural Science and Technology, 3(3):2348-1358.

Madhukumar, V., Seenappa, C., Lalitha, B.S., Sharanappa and Sanjay, M.T. 2018. Effect of organic farming practices on productivity, quality and economics of chilli hybrids in Central Dry Zone of Karnataka, India. International Journal of Current Microbiology and Applied Sciences, 7(2):2877-2885.
Pariari, A. and Das, S. 2017.Response of chilli (Capsicum annuum L.) to different sources and combination of nitrogen. International Journal of Current Microbiology and Applied Sciences, 6(4):972-976.

Pariari, A. and Khan, S. 2013. Integrated nutrient management of chilli (Capsicum annum L.,) in Gangetic alluvial plains. Journal of Crop and Weed,9(2):128-130.

Patel, L. C., Chakrabarty, S. and Googoi,A. K. 2015. Organic cultivation of chilli an assessment in West Tripura district of Tripura. Journal of Eco-friendly Agriculture, 10(1):15-19.

Reddy,G.C., Venkatachalapathi, V., Reddy,G.P.D and Hebbar, S.S. 2017. Study of different organic manure combination ongrowth and yield of chilli (Capsicum annum L.). Plant Archives, 17(1):472-474.

Singh, C.K., John, S.A.and Jaiswal, D.2014. Effect of organics on growth, yield and biochemical parameters of chilli (Capsicum annum L.). IOSR Journal of Agriculture and Veterinary Science (IOSR-JAVS), 7(1):27-32.

\section{How to cite this article:}

Afiya Khurshid, Faheema Mushtaq, Sumati Narayan, Shahnaz Mufti, Rehana Rasool, Iqtab Mushtaq Wani, Sameena Maqbool, Mir Tabasum Ashraf, Usma Jan, Humaira Nazir and Nawaz Ahmed. 2021. Effect of Various Organic Manures and Bio-fertilizers on Growth and Yield of Chilli (Capsicum annum L.) under Temperate Conditions of Kashmir. Int.J.Curr.Microbiol.App.Sci. 10(01): 3469-3474. doi: https://doi.org/10.20546/ijcmas.2021.1001.409 